\title{
An assessment of nitrogen saturation in Pinus banksiana plots in the Athabasca Oil Sands Region, Alberta
}

\author{
Dayna Lynn LAXTON*, Shaun A. WATMOUGH, Julian AHERNE and Justin STRAKER ${ }^{1)}$ \\ Environmental and Life Sciences, Trent University, 1600 West Bank Drive, Peterborough, ON K9J 7B8, Canada \\ ${ }^{1)}$ Stantec, 11-2042 Mills Road, Sidney, BC V8L 5X4, Canada \\ *corresponding author e-mail: daynalaxton@trentu.ca
}

ABSTRACT

During the past 15 years, there has been a dramatic increase in the amount of reactive nitrogen (N) in the atmosphere, leading to concerns that chronic elevated $N$ deposition may result in negative effects on natural ecosystems. This study examines the response of jack pine (Pinus banksiana) plots to $N$ air concentrations within the Athabasca Oil Sands Region (AOSR) in northern Alberta, which has experienced elevated $N$ emissions since the 1990s. Air concentrations of nitrogen dioxide $\left(\mathrm{NO}_{2}\right)$, ammonia, and nitric acid at the study plots are generally low although $\mathrm{NO}_{2}$ is strongly correlated with sulphur dioxide indicating an exposure gradient associated with industrial emissions. Nitrogen concentrations in P. banksiana foliage and two lichen indicator species (Hypogymnia physodes and Evernia mesomorpha) were significantly correlated with annual $\mathrm{NO}_{2}$ exposure. Relationships between $\mathrm{NO}_{2}$ (or $\mathrm{N}_{\text {exposure) and }}$ other aspects of $N$ cycling were less evident. Nitrogen content and carbon to nitrogen ratio in the forest floor and soil or potential net $N$ mineralization rates were not correlated with $N$ exposure. Nitrification was negligible suggesting efficient ecosystem immobilization of current $N$ deposition. Based on the response of foliage to $N$ exposure, sites closest to industrial activity appear to be in the early stages of $N$ saturation.

Key words: nitrogen, Pinus banksiana, lichens, critical levels/loads, ${ }^{15} \mathrm{~N}$, Canada

\section{INTRODUCTION}

The dramatic increase in emissions of reactive nitrogen during the past 15 years (Golder 2003) has led to concerns that chronic elevated nitrogen $(\mathrm{N})$ deposition may result in long-term negative effects on natural ecosystems (Aber et al. 1989; Galloway 1998). Nitrogen saturation ( $\mathrm{N}$ excess) in forest ecosystems is hypothesized to evolve through a series of stages, progressing from a low $\mathrm{N}$ availability system (Stage 0 ) to one incapable of processing and retaining the increased $\mathrm{N}$ input (Stage 3), ultimately resulting in nitrate $\left(\mathrm{NO}_{3}{ }^{-}\right)$leaching into groundwater and nitrous oxide $\left(\mathrm{N}_{2} \mathrm{O}\right)$ emissions back to the atmosphere (Aber et al. 1989; Vitousek et al. 1997; Aber et al. 1998). Additionally, foliar N content and soil $\mathrm{N}$ mineralization are expected to increase in concert with increases in biomass production during early stages of $\mathrm{N}$ saturation; later stages of $\mathrm{N}$ saturation may lead to shifts in species composition and potential nutrient imbalances eventually causing a decline in tree growth (Chapin 1980; Siccama et al. 1982; Nihlgård 1985; Lovett et al. 2000).

The Athabasca Oil Sands Region (AOSR) in northeastern Alberta is the largest commercially-operated crude oil deposit in North America and is responsible for making the Province of Alberta the top emitter of nitrogen oxides $\left(\mathrm{NO}_{\mathrm{x}}\right)$ in Canada (Environment Canada 2004). Moreover, current $\mathrm{NO}_{\mathrm{x}}$ emissions are expected to increase from 136 tonnes per day in 2003 to between 321-598 tonnes per day depending upon on future development (Golder 2003; NSMWG 2008). A variety of activities within the AOSR including open-pit mining, in situ recovery, extraction and upgrading operations contribute to the release of $\mathrm{NO}_{\mathrm{x}}$. Approximately half of the current $\mathrm{NO}_{\mathrm{x}}$ emissions are from the burning of diesel fuel used in mine fleets (NSMWG 2008). Nitrogen is largely (90-95\%) emitted in the form of nitric oxide (NO), which is quickly transformed to nitrogen dioxide $\left(\mathrm{NO}_{2}\right)$, with potential for conversion to a number of other $\mathrm{NO}_{\mathrm{x}}$ and nitric acid $\left(\mathrm{HNO}_{3}\right)$ while in the atmosphere. The $\mathrm{NO}_{x}$ emissions are then deposited to the landscape in the form of dry deposition and wet deposition at a gradient diminishing with distance from the source (Callesen \& Gundersen 2003; NSMWG 2008). The potential consequences of increased $\mathrm{N}$ deposition to terrestrial (and aquatic) ecosystems in the AOSR are of increasing concern (acidification/eutrophication), but determining the $\mathrm{N}$ status of an ecosystem can be difficult. Several studies have shown that stable

${ }^{15} \mathrm{~N}$ isotope ratios are a potentially valuable measure for regional assessments of $\mathrm{N}$ saturation (Nadelhoffer \& Fry 1994; Emmett 1998; Robinson 2001; Pardo et al. 2006). As $\mathrm{N}$ cycling increases, fractionation in favour of the lighter isotope occurs, leaving behind a soil pool enriched in the heavier isotope $\left({ }^{15} \mathrm{~N}\right)$ (Nadelhoffer \& Fry 1994). In addition, lichen species are known for their sensitivity to airborne pollutants [especially $\mathrm{NO}_{\mathrm{x}}$, sulphur dioxide $\left(\mathrm{SO}_{2}\right)$ and $\mathrm{O}_{3}$ ] and have high retention efficiencies (i.e., $\mathrm{N}$ uptake per gram of biomass) thereby making them efficient biomonitoring tools for atmospheric pollution (Berryman et al. 2004; Emmett 2007). 


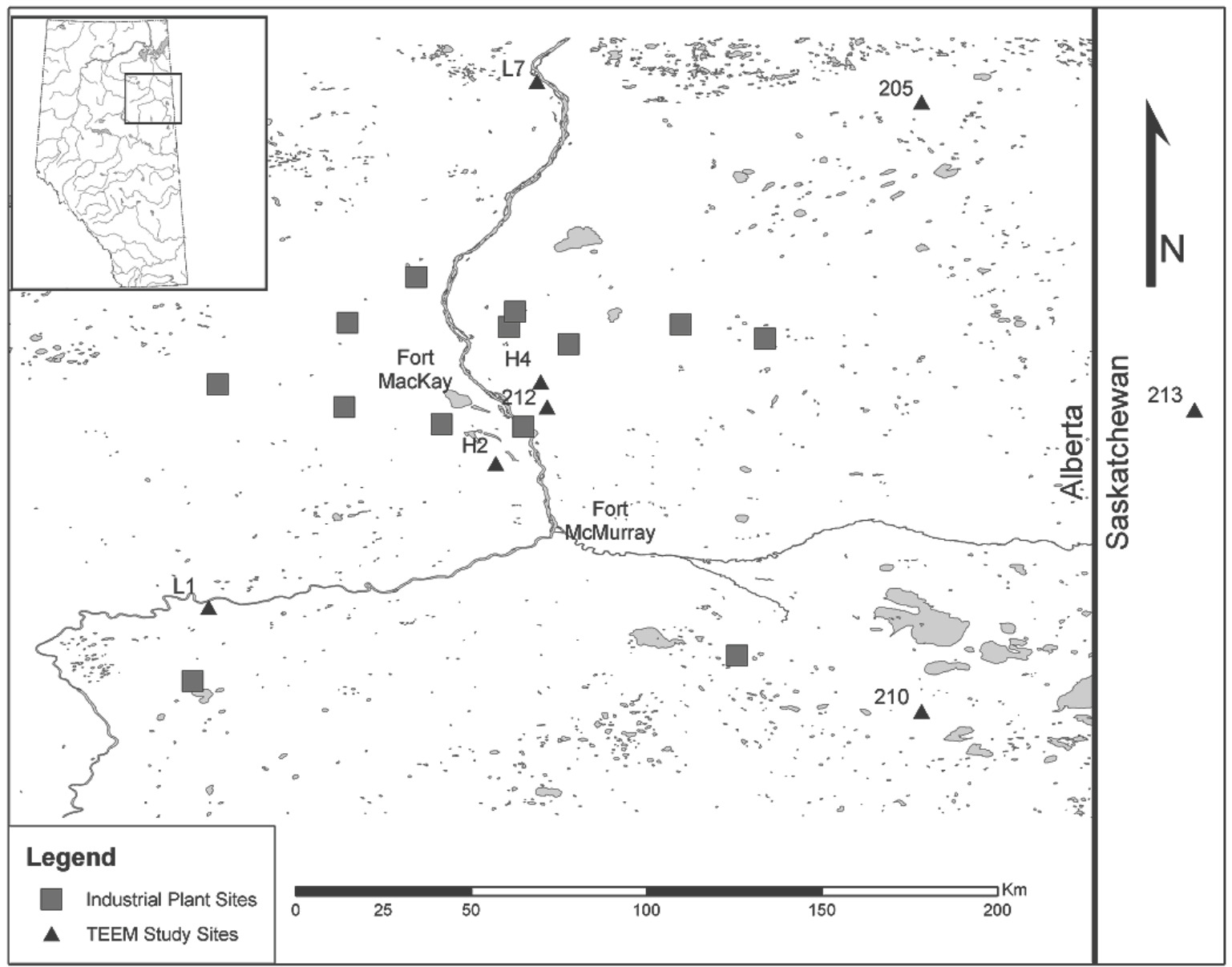

Fig. 1. Map of the Athabasca Oil Sands Region with Terrestrial Environmental Effects Monitoring study site locations ( $\Delta$ ) in relation to current oil sands industry operations $(\square)$. Map in-set shows relative location of the study region within the Province of Alberta.

The Terrestrial Environmental Effects Monitoring (TEEM) program, operated by the Wood Buffalo Environmental Association (WBEA), established a long-term study based on a network of monitoring sites across a (perceived) deposition gradient within the AOSR during the late 1990s. The TEEM study has continued to monitor the series of acid-sensitive plots dominated by jack pine (Pinus banksiana Lamb.) but, due to the sheer cost and technical difficulty of measuring deposition at such remote sites as well as determining region-specific deposition velocities, we currently do not have an accurate account of deposition levels throughout the region. Furthermore, the impact of current levels of $\mathrm{N}$ exposure on $\mathrm{N}$ dynamics at the TEEM plots has not been assessed. Therefore, the principal objective of this paper was to assess the ecological response to $\mathrm{N}$ exposure at the TEEM plots by examining the relationships between air concentrations of various $\mathrm{N}$ species and perceived indicators of $\mathrm{N}$ saturation such as foliar and lichen $\mathrm{N}$ concentration, forest floor $\mathrm{C}: \mathrm{N}$, isotopic signatures $\left(\delta^{15} \mathrm{~N}\right)$ and potential net soil mineralization/nitrification rates. In addition, $\mathrm{N}$ deposition to the TEEM plots was estimated using measured air concentrations and deposition velocities from a range of published values.

\section{METHODS}

\subsection{Study sites}

In 1998, the TEEM group established a network of long-term monitoring sites $(n=8)$ located within the AOSR. In 2001, an additional five sites were added to the network, including a site (ID: 213) located in northwestern Saskatchewan close to the Alberta-Saskatchewan border (Fig. 1). All monitoring sites were carefully chosen to be "ecologically analogous" (AMEC 2001) by meeting a suite of criteria including extensive landscape, vegetation, soil and other geographical characteristics, such as distance from roads and other development factors. The network design allowed for these sites to predominantly differentiate between high (those near industrial emission sources) and low (those distant from emission sources) acid-deposition areas within the AOSR [C.E. Jones (\& Associates Ltd) 2007]. It should be noted however, that since the establishment of this monitoring network, the once obvious high-low demarcation between sites has become less defined as production increases and development in the region expands. 
Study plots were delineated at each monitoring site, in a series of vegetation plots $\left(400 \mathrm{~m}^{2}\right)$ and a series of four separate soil plots $\left(400 \mathrm{~m}^{2}\right)$ all at a distance of at least $25 \mathrm{~m}$ from each vegetation plot. In addition to the variables explored in this study, stand age, site index, understory vegetation and lichen vigor are regularly measured and monitored at each study site [C.E. Jones (\& Associates Ltd) 2007].

The current study is limited to eight TEEM monitoring sites that have consistent data sets (specifically air concentration measurements) and supplementary data collected by Trent University. Statistical analyses were carried out in STATISTICA7. Parametric and nonparametric statistical tests were applied based on the distributions of the data.

\subsection{Air concentration monitoring and total deposition}

Air concentrations of $\mathrm{NO}_{2}, \mathrm{NH}_{3}, \mathrm{HNO}_{3}$, and $\mathrm{SO}_{2}$ were measured at 8 of 13 TEEM plots (L1, L7, H2, H4, 205, 210, 212, 213; Fig. 1) using passive samplers. The samplers are located 3-5 metres above the forest canopy and exposed on a monthly basis from April to October and bi-monthly during the winter period. The $\mathrm{NO}_{2}$ and $\mathrm{SO}_{2}$ sampling started in 1999 while $\mathrm{HNO}_{3}$ and $\mathrm{NH}_{3}$ started during 2005. Ammonia $\left(\mathrm{NH}_{3}\right)$ was measured using an Ogawa ${ }^{\mathrm{TM}}$ sampler (Ogawa \& Co., USA, Inc.) and extracted with deionised water and analysed colourimetrically (Roadman et al. 2003); $\mathrm{HNO}_{3}$ was measured using a nylon filter exposed inside a commercially available polycarbonate Petri dish (Bytnerowicz et al. 2005) and $\mathrm{NO}_{2}$ as well as $\mathrm{SO}_{2}$ were sampled using a patented sampler designed and analysed by MAXXAM Analytics (Edmonton, AB). For further details on $\mathrm{NH}_{3}$ and $\mathrm{HNO}_{3}$ monitoring see Bytnerowicz et al. (2010, this issue).

Since mid 2005, $\mathrm{NO}_{2}, \mathrm{NH}_{3}$ and $\mathrm{HNO}_{3}$ have been consistently deployed at all eight plots, with the exception of site 212 where monitoring of $\mathrm{NH}_{3}$ and $\mathrm{HNO}_{3}$ did not commence until May 2007. Nonetheless, the 2-year average (2007-2008) for $\mathrm{NH}_{3}$ and $\mathrm{HNO}_{3}$ at site 212 was not significantly different from the other sites (20062008) $\left(\mathrm{NH}_{3}\right.$ : Kruskal Wallis $p=0.08, \mathrm{HNO}_{3}$ : ANOVA $p=0.76)$.

The long-term (3-year) annual average dry deposition rate $\left(\mathrm{kg} \mathrm{ha}^{-1}\right)$ at each site was estimated using measured air concentrations $\left(\mu \mathrm{g} \mathrm{m}^{-3}\right)$ and literaturebased estimates of dry deposition velocities, as regionspecific deposition velocities are not available (particularly for $\mathrm{NO}_{2}$ and $\mathrm{NH}_{3}$ ). To account for the wide range in reported deposition velocities (Hanson \& Lindberg 1990; Peters \& Bruckner-Schatt 1995) a 'low' and 'high' deposition rate were estimated based on the range of published velocity values (Rihm 1994; Zhang et al. 2004; Zhang et al. 2009). In addition to dry deposition, wet deposition values were obtained from a regional-scale $(35 \mathrm{~km} \times 35 \mathrm{~km})$ deposition map from Environment Canada (NAtChem database) (Vet \& Shaw 2006; Zhang et al. 2004) and used to estimate long-term average total (wet + dry) $\mathrm{N}(\mathrm{TN})$ deposition at each TEEM plot.

\subsection{Analysis of Evernia mesomorpha and Hypogymnia physodes}

Lichen samples of Hypogymnia physodes and Evernia mesomorpha were collected 1.5 to $2 \mathrm{~m}$ above the ground on the outermost branches of Pinus banksiana within each TEEM plot. Both of these species are easily recognizable and abundant at all sites. Samples were placed in clean Kapak bags as described by Berryman et al. (2004). In the laboratory, each sample was cleaned of dirt, bark pieces and any remnants of undesired species using forceps. The samples were then oven-dried at $70{ }^{\circ} \mathrm{C}$ and ground using a vegetation mill at Pacific Soil Analysis Inc. in Richmond, B.C. Analysis of total N and sulphur (S) content (\%) was conducted by Alberta Research Council, Edmonton via dry combustion of 150-250 mg of the oven-dried sample using a LECO TruSpec ${ }^{\circledR} \mathrm{CN}$ Determinator at $950{ }^{\circ} \mathrm{C}$.

\section{4. ${ }^{15} N$ natural abundance analysis}

Soil samples from the litter-fibric-humic layer (LFH) and mineral A-horizon soils were collected and the samples were air dried and passed through a $2 \mathrm{~mm}$ sieve. In 2004, foliage samples were collected for three separate year classes (current year's growth, as well as 1-year old (2003) and 2-year old needles (2002)). The needles were oven-dried at $70{ }^{\circ} \mathrm{C}$ and ground in a vegetation mill. Fine root samples $(<5 \mathrm{~mm})$ were collected in July 2008 from the base of five trees at each of the eight TEEM sites. All samples were cleaned of debris and further pulverised to a fine powder using a ball-mill mixer (wig-L-bug ${ }^{\circledR}$, Pike Technologies). Natural abundance isotopic analysis $\left(\delta^{15} \mathrm{~N}\right)$ as well as $\% \mathrm{C}$ and $\% \mathrm{~N}$ analysis was conducted on all soil, foliage and root samples using a Micromass Isoprime Continuous Flow Isotope Ratio Mass Spectrometer (CF-IRMS) coupled with a Eurovector EA3000 Elemental Analyzer. Known standards (NIST1547, LG(F), DG (A1), USGS40) were analysed together with the samples for machine calibration and data correction. There was no significant difference $(p=0.74)$ in foliar $\mathrm{N}$ and $\delta^{15} \mathrm{~N}$ between different age-class needles and therefore the average across all three year classes was used in further analysis.

\subsection{Soil processes}

Potential net ammonification, nitrification and mineralization were measured using soil samples incubated in polyethylene bags modified from Eno (1960). This method estimates net mineralization and nitrification as changes in soil $\mathrm{NH}_{4}{ }^{+}$and $\mathrm{NO}_{3}{ }^{-}$during an incubation period. At the start of the incubation period a set of nonincubated (initial) soil samples were collected from each site at two depths $(0-10 \mathrm{~cm}$ and $10-20 \mathrm{~cm})$ in July 2008. Each sample was placed in a sterile whirl-pak bag (Forestry Suppliers Inc.) and kept cool during transport 
Tab. 1. Data summary (minimum, maximum and mean) for investigated air concentrations of major air pollutants and ecosystem response indicator parameters of $\mathrm{N}$ saturation measured at $P$. banksiana monitoring sites in the Athabasca Oil Sands Region, Alberta Canada $(\mathrm{n}=8)$.

\begin{tabular}{|c|c|c|c|c|}
\hline Variable & Units & Min & Max & Mean \\
\hline $\mathrm{NO}_{2}$ & $\mu \mathrm{g} \mathrm{m}^{-3}$ & 0.48 & 7.73 & 3.34 \\
\hline $\mathrm{NH}_{3}$ & $\mu \mathrm{g} \mathrm{m}^{-3}$ & 0.71 & 1.10 & 0.94 \\
\hline $\mathrm{HNO}_{3}$ & $\mu \mathrm{g} \mathrm{m}^{-3}$ & 0.36 & 0.72 & 0.55 \\
\hline $\mathrm{SO}_{2}$ & $\mu \mathrm{g} \mathrm{m}^{-3}$ & 1.45 & 5.85 & 3.21 \\
\hline LFH N & $\%$ & 0.46 & 0.79 & 0.62 \\
\hline LFH C:N & & 32 & 42 & 38 \\
\hline A-horizon $\mathrm{N}$ & $\%$ & 0.01 & 0.08 & 0.04 \\
\hline Foliage N & $\%$ & 0.80 & 1.04 & 0.93 \\
\hline Foliage $\mathrm{S}$ & $\%$ & 0.06 & 0.09 & 0.07 \\
\hline Fine Root N & $\%$ & 0.26 & 0.44 & 0.36 \\
\hline Evernia mesomorpha $\mathrm{N}$ & $\%$ & 0.58 & 0.90 & 0.77 \\
\hline Hypogymnia physodes $\mathrm{N}$ & $\%$ & 0.49 & 0.71 & 0.58 \\
\hline Evernia mesomorpha $\mathrm{S}$ & $\%$ & 0.08 & 0.13 & 0.11 \\
\hline Hypogymnia physodes $\mathrm{S}$ & $\%$ & 0.07 & 0.11 & 0.08 \\
\hline $\mathrm{LFH} \delta^{15} \mathrm{~N}$ & $\%$ & -4.54 & -1.79 & -2.62 \\
\hline A-horizon $\delta^{15} \mathrm{~N}$ & $\%$ & 0.55 & 3.01 & 2.14 \\
\hline Foliage $\delta^{15} \mathrm{~N}$ & $\%$ & -3.59 & -1.94 & -2.81 \\
\hline Fine $\operatorname{Root} \delta^{15} \mathrm{~N}$ & $\%$ & -7.04 & -0.99 & -3.72 \\
\hline Net ammonification rate & $\mathrm{mg} \mathrm{N}-\mathrm{NH}_{4}^{+} \mathrm{kg} \mathrm{C}^{-1} \mathrm{y}^{-1}$ & 122 & 6235 & 1193 \\
\hline Net nitrification rate & $\mathrm{mg} \mathrm{N}-\mathrm{NO}_{3}^{-} \mathrm{kg} \mathrm{C}^{-1} \mathrm{y}^{-1}$ & 0 & 0.44 & 0.10 \\
\hline Net mineralization rate & $\operatorname{mg~N~kg~C}{ }^{-1} \mathrm{y}^{-1}$ & 122 & 6235 & 1193 \\
\hline
\end{tabular}

to the lab. The initial soil $\mathrm{NH}_{4}{ }^{+}$and $\mathrm{NO}_{3}^{-}$was determined immediately, where 5 grams of sieved soil was extracted with $50 \mathrm{~mL}$ of $1 \mathrm{M} \mathrm{KCl}$ for 2 hours. The supernatant was then carefully drawn into a syringe and filtered using a stainless steel syringe filter holder and a $0.7 \mu \mathrm{m}$ glass fibre filter (Cole Parmer). Filtered extracts were analyzed for $\mathrm{NH}_{4}{ }^{+}-\mathrm{N}(630 \mathrm{~nm})$ and $\mathrm{NO}_{3}{ }^{-} \mathrm{N}(550$ $\mathrm{nm}$ ) using a high-resolution continuous auto analyzer (Bran + Luebbe Auto Analyser 3). In addition, a soil sub-sample was dried for 48 hours at $60{ }^{\circ} \mathrm{C}$ to determine the soil water content and subsequent mass of soil used for the extractions. The remaining soil samples were then incubated at $10{ }^{\circ} \mathrm{C}$ for 55 days and the above extraction methods were repeated.

Net ammonification, nitrification and mineralization rates were calculated by subtracting the initial mineral $\mathrm{N}$ content $\left(\mathrm{NH}_{4}{ }^{+}-\mathrm{N}\right.$ and $\left.\mathrm{NO}_{3}{ }^{-} \mathrm{N}\right)$ in $\mu \mathrm{g} \mathrm{g}^{-1}$ of dry soil from the incubated mineral $\mathrm{N}$ content. These values were then normalized by $\% \mathrm{C}$ content of soil and expressed as a net annual rate $\left(\mathrm{mg} \mathrm{N} \mathrm{kg} \mathrm{C}^{-1} \mathrm{y}^{-1}\right)$.

\subsection{Statistical analysis}

In addition to the statistical analyses mentioned above, Pearson correlation coefficients were used to determine the presence of relationships between the investigated variables (Data Analysis, Microsoft Excel). All data were found to be normally distributed with the exception of the soil processes (net nitrification, ammonification and mineralization), in which an outlier (site L1) skewed the data. This prompted the use of nonparametric statistical correlation (Spearman Rank Order) tests for these three variables in relation to the rest of the data set. Correlations were found to be significant at the $95 \%$ and $99 \%$ confidence levels $(p<0.05$, $p<0.01)$.

\section{RESULTS}

\subsection{Air concentrations and deposition estimates}

Air concentrations of $\mathrm{NO}_{2}, \mathrm{NH}_{3}$ and $\mathrm{HNO}_{3}$ were generally very low (Tab. 1). The widest range in measured annual average air concentrations during the study period (2006-2008) was observed for $\mathrm{NO}_{2}$ (0.48 to 7.73 $\mu \mathrm{g} \mathrm{m}^{-3}$ ). Ammonia air concentrations (three year annual average) were between 0.71 and $1.10 \mu \mathrm{g} \mathrm{m}^{-3}$ and $\mathrm{HNO}_{3}$ air concentrations ranged from 0.36 to $0.72 \mu \mathrm{g} \mathrm{m}^{-3}$.

Estimates of annual average wet $\mathrm{N}$ deposition were low, between 0.74 and $1.15 \mathrm{~kg} \mathrm{ha}^{-1} \mathrm{y}^{-1}$ (Tab. 2). Estimated TN deposition at the study sites varied depending on the method used to estimate dry deposition. Under our 'low' deposition estimate, TN ranged between 2.45 and $3.8 \mathrm{~kg} \mathrm{~N} \mathrm{ha}^{-1} \mathrm{y}^{-1}$, where under the 'high' deposition estimate TN ranged between 7.6 and $13.4 \mathrm{~kg} \mathrm{~N} \mathrm{ha}^{-1} \mathrm{y}^{-1}$. The highest estimate of TN deposition was for site $\mathrm{H} 4$, just north-west of where much of the current open-pit mining is located. The lowest TN deposition estimate was for site 205 , which is the most north-easterly site (Fig. 1). Air concentration of $\mathrm{NO}_{2}$ was not significantly correlated with other $\mathrm{N}$ species $\left(\mathrm{NH}_{3}\right.$ and $\left.\mathrm{HNO}_{3}\right)$ but was very strongly correlated with $\mathrm{SO}_{2}$. The strong positive correlation between $\mathrm{SO}_{2}$ and $\mathrm{NO}_{2}$, as well as the strong negative correlation between altitude and $\mathrm{NO}_{2}$, reflect the change in air chemistry with distance from emission sources (Tab. 3).

\subsection{Air concentrations and perceived response indicators}

Nitrogen concentrations in foliage ranged between 0.80 and $1.04 \%$ and were between 0.49 and $0.90 \%$ in Evernia mesomorpha and Hypogymnia physodes 
Tab. 2. Estimated annual average nitrogen deposition (2006-2008) at each TEEM site for both the 'low' and 'high' deposition estimates using differing dry deposition velocities and modelling wet deposition estimates from NAtChem.

\begin{tabular}{lccc}
\hline Site & $\begin{array}{r}\text { Total wet deposition } \\
\left(\mathrm{kg} \mathrm{N} \mathrm{ha}^{-1} \mathrm{y}^{-1}\right)\end{array}$ & $\begin{array}{r}\text { Total low dry deposition estimate } \\
\left(\mathrm{kg} \mathrm{N} \mathrm{ha}^{-1} \mathrm{y}^{-1}\right)\end{array}$ & $\begin{array}{r}\text { Total high dry deposition estimate } \\
\left(\mathrm{kg} \mathrm{N} \mathrm{ha}^{-1} \mathrm{y}^{-1}\right)\end{array}$ \\
\hline 205 & 0.75 & 1.70 & 6.85 \\
210 & 1.15 & 1.84 & 8.32 \\
212 & 0.86 & 2.34 & 11.27 \\
213 & 0.93 & 2.28 & 9.81 \\
$\mathrm{H} 2$ & 0.96 & 2.73 & 10.72 \\
$\mathrm{H} 4$ & 0.86 & 2.94 & 12.59 \\
L1 & 1.07 & 2.03 & 8.73 \\
L7 & 0.74 & 2.05 & 8.80 \\
\hline
\end{tabular}

Tab. 3. Pearson Product Moment correlations for geographical, meteorological and deposition factors across a deposition gradient in the Athabasca Oil Sands Region, Alberta Canada. ${ }^{\text {a)}}$ : $r$-values are significant at the $95 \%$ confidence level $(p<0.05) ;{ }^{\text {b) }}: r$-values are significant at the $99 \%$ confidence level $(p<0.001)$.

\begin{tabular}{lccccccccc}
\hline & Latitude & Longitude & $\begin{array}{c}\text { Altitude } \\
(\mathrm{m} \text { asl })\end{array}$ & $\begin{array}{c}\text { Rainfall } \\
(\mathrm{mm})\end{array}$ & $\begin{array}{c}\mathrm{Av} . \mathrm{Temp} . \\
\left({ }^{\circ} \mathrm{C}\right)\end{array}$ & $\begin{array}{c}\mathrm{NO}_{2} \\
\left(\mu \mathrm{g} \mathrm{m}^{-3}\right)\end{array}$ & $\begin{array}{c}\mathrm{SO}_{2} \\
\left(\mu \mathrm{g} \mathrm{m}^{-3}\right)\end{array}$ & $\begin{array}{c}\mathrm{NH}_{3} \\
\left(\mu \mathrm{g} \mathrm{m}^{-3)}\right.\end{array}$ \\
\hline $\begin{array}{l}\text { Latitude } \\
\text { Longitude }\end{array}$ & & & & & & & & & \\
Altitude & $(\mathrm{m}$ a.s.1. $)$ & -0.48 & 0.48 & & & & & & \\
Rainfall & $(\mathrm{mm})$ & $-0.81^{\mathrm{a})}$ & -0.19 & 0.36 & & & & & \\
Av. Temp. & $\left({ }^{\circ} \mathrm{C}\right)$ & $-0.91^{\mathrm{b})}$ & 0.09 & $0.76^{\mathrm{a})}$ & $0.79^{\mathrm{a})}$ & & & & \\
$\mathrm{NO}_{2}$ & $\left(\mu \mathrm{g} \mathrm{m}^{3}\right)$ & 0.05 & -0.48 & $-0.72^{\mathrm{a})}$ & 0.20 & -0.28 & & & \\
$\mathrm{SO}_{2}$ & $\left(\mu \mathrm{g} \mathrm{m}^{-3}\right)$ & 0.02 & -0.56 & -0.69 & 0.29 & -0.21 & $0.97^{\text {b) }}$ & & \\
$\mathrm{NH}_{3}$ & $\left(\mu \mathrm{g} \mathrm{m}^{-3}\right)$ & -0.38 & -0.04 & 0.15 & 0.60 & 0.39 & 0.53 & 0.51 & 0.24 \\
$\mathrm{HNO}_{3}$ & $\left(\mu \mathrm{g} \mathrm{m}^{-3}\right)$ & -0.10 & -0.10 & 0.06 & 0.31 & 0.09 & 0.28 & 0.24 & 0.24 \\
\hline
\end{tabular}

(Tab.1). Potential net mineralization rates ranged between 122 and $6235 \mathrm{mg} \mathrm{N} \mathrm{kg} \mathrm{C}^{-1} \mathrm{y}^{-1}$ (Tab. 1), with the highest mineralization rate at site L1 located southwest of the majority of oil sands activity and secondhighest rate at site $\mathrm{H} 4\left(1104 \mathrm{mg} \mathrm{N} \mathrm{kg} \mathrm{C}^{-1} \mathrm{y}^{-1}\right)$. Elemental $\mathrm{N}$ concentration in Pinus banksiana foliage was significantly correlated $(r=0.74, p<0.05)$ with $\mathrm{NO}_{2}$ (Tab. 4). Similarly, significant correlations with $\mathrm{NO}_{2}$ were observed for the lichen species Evernia mesomorpha $(r$ $=0.81, p<0.05)$ and Hypogymnia physodes $(r=0.89, p$ $<0.01$ ) (Fig. 2). The stable isotope signature of the foliage had a weak negative correlation with $\mathrm{NO}_{2}(r=$ -0.57), while no correlations existed between air concentrations of $\mathrm{NO}_{2}, \mathrm{NH}_{3}$ and $\mathrm{HNO}_{3}$ with forest floor $\mathrm{C}: \mathrm{N}$ ratio and net soil mineralization rate (Tab. 4).

\subsection{Ecosystem-level cycling}

In order to evaluate the $\mathrm{N}$-cycling processes at the site-level, correlations between soil (LFH, A-horizon), fine root and foliar $\mathrm{N}$ and $\delta^{15} \mathrm{~N}$, and net mineralization/nitrification rates were compared (Tab. 5). Potential net $\mathrm{N}$ mineralization was dominated by net ammonification and net nitrification rates were extremely low (Tab. 1). The $\mathrm{N}$ concentration in the LFH was negatively correlated with net mineralization and ammonification $(r=-0.76, p<0.05)$, whereas $\delta^{15} \mathrm{~N}$ in foliage was positively correlated with net mineralization and ammonification $(r=0.76, p<0.05)$. Net nitrification was positively correlated with $\delta^{15} \mathrm{~N}$ in the A-horizon soil $(r=0.79, p<0.05)$. No other statistically significant relationships were observed.

\section{DISCUSSION}

\subsection{Air concentrations and deposition}

Air concentrations of $\mathrm{NO}_{2}$ showed a clear gradient of decreasing concentration across the region that is associated with anthropogenic sources. The measured $\mathrm{NO}_{2}$ air concentrations were strongly correlated with $\mathrm{SO}_{2}$ which is a well-known anthropogenic pollutant. However, in general, the air concentrations are relatively low, despite the high levels of $\mathrm{NO}_{\mathrm{x}}$ and $\mathrm{SO}_{2}$ emissions.

There are few, if any, annual $\mathrm{NO}_{2}$ concentrations reported for background regions. Comparatively, it is not surprising that the observations in the AOSR are at the lower end of the observed concentrations reported for various Canadian cities $\left(\sim 10\right.$ to $50 \mu \mathrm{g} \mathrm{m}^{-3}$ ) (Burnett et al. 1998; Gilbert et al. 2005; Atari et al. 2008) and at the lower end of concentrations observed across many areas of Europe ( $\sim 16$ to $\left.46 \mu \mathrm{g} \mathrm{m}^{-3}\right)$ (Kirby et al. 1998; Grodzińska-Jurczak \& Szarek-Lukaszewska 1999; Lebret et al. 2000). The range of $\mathrm{NH}_{3}$ air concentrations observed in the region are also lower than the annual averages observed throughout many areas of Canada, including Southern Ontario $\left(6 \mu \mathrm{g} \mathrm{m}^{-3}\right)$ (Lillyman \& Buset 2008). 
Tab. 4. Correlations between annual average air concentrations of various nitrogen $(\mathrm{N})$ species and potential ecosystem response variables for factors measured at $P$. banksiana monitoring sites in the Athabasca Oil Sands Region, Alberta, Canada. *: Spearman Rank Order Correlation coefficients, data not normally distributed. All other data: Pearson Product Moment Correlation coefficients; ${ }^{\text {a) }}: r$-values are significant at the $95 \%$ confidence level $(p$ $<0.05) ;{ }^{\text {b) }}: r$-values are significant at the $99 \%$ confidence level $(p<0.01)$.

\begin{tabular}{lccc}
\hline Response Variables & \multicolumn{3}{c}{ Air Concentration } \\
\cline { 2 - 4 } & $\mathrm{NO}_{2}\left(\mu \mathrm{g} \mathrm{m}^{-3}\right)$ & $\mathrm{NH}_{3}\left(\mu \mathrm{g} \mathrm{m}^{-3}\right)$ & $\mathrm{HNO}_{3}\left(\mu \mathrm{g} \mathrm{m}^{-3)}\right.$ \\
\hline N Foliage (\%) & $\left.0.74^{\mathrm{a}}\right)$ & 0.59 & 0.11 \\
$\delta^{15}$ N Foliage & -0.57 & -0.22 & 0.08 \\
$\mathrm{~N}$ Evernia (\%) & $0.81^{\mathrm{a}}$ & 0.09 & -0.12 \\
$\mathrm{~N}$ Hypogymnia (\%) & $0.89^{\mathrm{b})}$ & 0.35 & 0.20 \\
LFH C:N & 0.09 & 0.04 & -0.01 \\
Mineralization rate* $\left(\mathrm{mg} \mathrm{N} \mathrm{kg} \mathrm{C}^{-1} \mathrm{y}^{-1}\right)$ & -0.24 & 0.14 & 0.00 \\
\hline
\end{tabular}
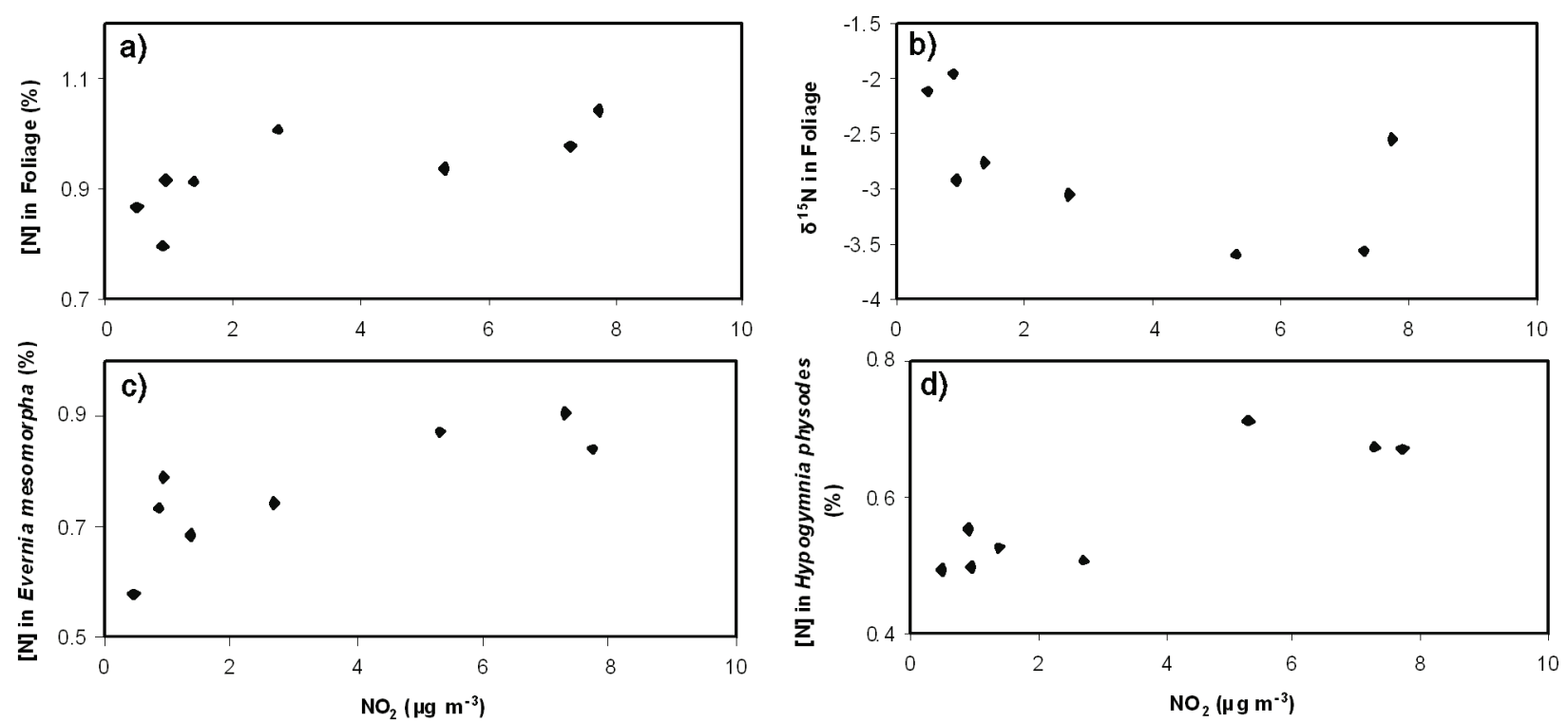

Fig. 2. Correlations between measured average annual $\mathrm{NO}_{2}$ air concentrations $\left(\mu \mathrm{g} \mathrm{m}^{-3}\right)$ and; a) $\% \mathrm{~N}$ in Pinus banksiana foliage, b) the natural abundance of ${ }^{15} \mathrm{~N}$ in Pinus banksiana foliage, c) $\% \mathrm{~N}$ in Evernia mesomorpha, d) \% $\mathrm{N}$ in Hypogymnia physodes.

Tab. 5. Pearson Product Moment correlation coefficients for ecosystem-level N-related factors measured at $P$. banksiana monitoring sites in the Athabasca Oil Sands Region, Alberta, Canada. *:Spearman Rank Order Correlation coefficients, data not normally distributed. All other data: Pearson Product Moment Correlation coefficients; ${ }^{\text {a)}}$ : $r$-values are significant at the $95 \%$ confidence level $(p<0.05)$.

\begin{tabular}{|c|c|c|c|c|c|c|c|c|c|}
\hline & $\begin{array}{l}\% \mathrm{~N} \\
\mathrm{LFH}\end{array}$ & $\begin{array}{l}\text { LFH } \\
\text { C:N }\end{array}$ & $\begin{array}{c}\% \mathrm{~N} \\
\text { A-horizon }\end{array}$ & $\begin{array}{l}\% \mathrm{~N} \\
\text { Foliage }\end{array}$ & $\begin{array}{l}\% \mathrm{~N} \\
\text { Roots }\end{array}$ & $\begin{array}{l}\delta^{15} \mathrm{~N} \\
\mathrm{LFH}\end{array}$ & $\begin{array}{c}\delta^{15} \mathrm{~N} \\
\text { A-horizon }\end{array}$ & $\begin{array}{l}\delta^{15} \mathrm{~N} \\
\text { Foliage }\end{array}$ & $\begin{array}{l}\delta^{15} \mathrm{~N} \\
\text { Roots }\end{array}$ \\
\hline \multicolumn{10}{|l|}{$\% \mathrm{~N} \mathrm{LFH}$} \\
\hline LFH C:N & -0.10 & & & & & & & & \\
\hline$\% \mathrm{~N}$ A-horizon & 0.66 & -0.45 & & & & & & & \\
\hline$\% \mathrm{~N}$ Foliage & 0.38 & -0.10 & 0.31 & & & & & & \\
\hline$\%$ N Roots & 0.56 & 0.48 & 0.23 & 0.41 & & & & & \\
\hline$\delta^{15} \mathrm{~N}$ LFH & 0.57 & 0.39 & 0.15 & -0.19 & 0.28 & & & & \\
\hline$\delta^{15} \mathrm{~N}$ A-horizon & 0.10 & 0.29 & -0.23 & -0.21 & 0.08 & 0.11 & & & \\
\hline$\delta^{15} \mathrm{~N}$ Foliage & -0.63 & 0.30 & -0.47 & -0.57 & -0.40 & 0.04 & 0.43 & & \\
\hline$\delta^{15} \mathrm{~N}$ Roots & 0.13 & 0.06 & -0.39 & -0.62 & -0.07 & 0.40 & 0.29 & 0.05 & \\
\hline $\begin{array}{l}\text { Ammonification rate* } \\
\left(\mathrm{mg} \mathrm{N}^{*} \mathrm{NH}_{4}+\mathrm{kg} \mathrm{C}^{-1} \mathrm{y}^{-1}\right)\end{array}$ & $-0.76^{\mathrm{a})}$ & -0.05 & -0.40 & -0.31 & -0.50 & -0.55 & 0.36 & $0.76^{\mathrm{a})}$ & -0.02 \\
\hline $\begin{array}{l}\text { Nitrification rate* } \\
\left(\mathrm{mg} \mathrm{N}^{*} \mathrm{NO}_{3}^{-} \mathrm{kg} \mathrm{C}^{-1} \mathrm{y}^{-1}\right)\end{array}$ & 0.05 & 0.33 & 0.14 & -0.30 & 0.52 & 0.25 & $0.79^{\text {a) }}$ & 0.27 & 0.08 \\
\hline $\begin{array}{l}\text { Mineralization rate* } \\
\left(\mathrm{mg} \mathrm{N} \mathrm{kg} \mathrm{C}^{-1} \mathrm{y}^{-1}\right)\end{array}$ & $-0.76^{\mathrm{a})}$ & -0.05 & -0.40 & -0.31 & -0.50 & -0.55 & 0.36 & $0.76^{\mathrm{a})}$ & -0.02 \\
\hline
\end{tabular}


The TN deposition estimates were calculated using the measured air concentrations for dry deposition species in addition to wet deposition estimates from the NAtChem database. The wet deposition estimates do not vary substantially between sites (Tab. 2) and are considered to be much lower than dry deposition (NSMWG 2008). The estimated 'low' TN deposition range is generally lower than the estimates for other parts of Canada and the United States, in regions typically affected by acid deposition [Watmough et al. 2005 (4-17 kg N ha $\left.{ }^{-1} \mathrm{y}^{-1}\right)$; Pardo et al. $2006(1.5-10 \mathrm{~kg} \mathrm{~N}$ $\mathrm{ha}^{-1} \mathrm{y}^{-1}$ N.A.)], although, the 'high' TN deposition range is comparable to these regions. These values of TN deposition are still substantially lower than $\mathrm{N}$ deposition observed in many parts of Europe (Dise \& Wright 1995; Pardo et al. 2006), but are substantial for boreal ecosystems that typically receive low (background) $\mathrm{N}$ inputs.

The difference between the low and high deposition estimates is driven primarily by differences in deposition velocities for $\mathrm{NO}_{2}$ and $\mathrm{NH}_{3}$. The high dry deposition estimate is dominated primarily by $\mathrm{NH}_{3}(70 \%)$, compared with the low deposition scenario (27\%). Currently, $\mathrm{NH}_{3}$ is not of major importance in the region although, there is evidence of $\mathrm{NH}_{3}$ emissions from oil sands industry stacks and the catalytic converters in the exhaust systems of mine fleet vehicles. Current observations suggest the $\mathrm{NH}_{3}$ is associated with anthropogenic sources, and the weak correlation between $\mathrm{NO}_{2}$ and $\mathrm{NH}_{3}(r=0.54)$ increases to 0.83 with the elimination of site 213, which is located in Saskatchewan and potentially impacted by local Provincial sources (fertilizer production).

\subsection{Ecosystem response to $N$}

At the ecosystem scale, there is a series of effects usually observed with increased $\mathrm{N}$ deposition (Aber et al. 1989; Vitousek 1997; Galloway 1998). The boreal forest in Canada is a nutrient-limited ecosystem, dominated by slow-growing species with efficient $\mathrm{N}$ cycling and storage (Tamm 1991; Callesen \& Gundersen 2003). $\mathrm{N}$-efficient ecosystems typically allocate $\mathrm{N}$ to roots and long-lived foliage as oppose to stem-wood and bark (Smith et al. 1999). As a result, coniferous species have a lower biological demand and thus, are better adapted to a low supply of nutrients (Pardo et al. 2007). In fact, most coniferous forests need less than $10 \mathrm{~kg} \mathrm{~N} \mathrm{ha}^{-1} \mathrm{y}^{-1}$ for new biomass production (Encke 1986).

We found a strong positive correlation between the annual average $\mathrm{NO}_{2}$ concentration and foliar $\mathrm{N}$, consistent with previous reports of increasing foliar $\mathrm{N}$ with increasing $\mathrm{N}$ exposure (Pardo et al. 2006). A weak negative correlation was observed between $\mathrm{NO}_{2}$ concentration and foliar $\delta^{15} \mathrm{~N}$, which has been previously suggested to strongly correlate with $\mathrm{N}$ deposition (McNulty et al. 1991, Pardo et al. 2006; 2007) (Fig. 2b). Lichens living on trees obtain most of their nutrients from the air as dry deposition and from solutes in precipitation and fog (Fenn et al. 2007). This makes them potentially very sensitive to air pollution and thus potential early indicators of $\mathrm{N}$ impacts to the forest. In fact, the majority of lichen-rich communities occur in nutrient-poor ecosystems where, potentially, increased $\mathrm{N}$ deposition may cause their extinction (Sutton et al. 2004). In the present study N concentrations in Evernia mesomorpha and Hypogymnia physodes showed strong relationships with $\mathrm{NO}_{2}$ air concentrations (Fig. 2c, d) and $\mathrm{SO}_{2}$ (not shown).

In contrast to the foliar and lichen $\mathrm{N}$ concentrations, forest floor (LFH) C:N ratio, and potential net soil mineralization/nitrification rates were not correlated with $\mathrm{N}$ air concentrations. This may be a factor of time, where the increased $\mathrm{N}$ concentrations of the living foliage has not yet influenced the forest floor and soil pools through $\mathrm{N}$ inputs via litter-fall flux. While not apparently affected by $\mathrm{N}$ exposure, potential net mineralization was positively correlated with $\delta^{15} \mathrm{~N}$ in foliage but is negatively correlated with $\mathrm{N}$ concentration in the forest floor (LFH), which is contrary to what would be expected (McNulty et al. 1996; Pardo et al. 2006). However, net potential nitrification was positively correlated with $\delta^{15} \mathrm{~N}$ in the A-horizon, consistent with the hypothesis that increased nitrification leads to increased nitrate leaching, resulting in the enrichment of ${ }^{15} \mathrm{~N}$ in the soil pool (Nadelhoffer \& Fry 1994; Pardo et al. 2006). Overall, however, there is limited evidence of alteration of $\mathrm{N}$ cycling at the study sites in response to $\mathrm{N}$ exposure at this time.

Despite the observed response to $\mathrm{N}$ exposure (across a gradient) in foliage and lichens, the foliage and lichen $\mathrm{N}$ concentrations $(0.49-1.04 \%)$ are still within range of those observed in areas with minimal air pollution impact (Munson \& Timmer 1995; Tjoelker et al. 1999). The $\mathrm{N}$ concentrations in the lichen Hypogymnia physodes also fall within the range of values from other studies (0.42-2.56\%) (Kulbin 1990; Bruteig 1992; Dahlman \& Persson 2003). Additionally, the mineralization rates at the TEEM sites, with the exception of site L1, are low with almost no evidence of nitrification. According to Emmett (1998), the relative change in ${ }^{15} \mathrm{~N}$ in foliage under elevated $\mathrm{N}$ deposition is greater than that of soils, because the soil has a much longer timeline for change due to the relatively large inactive soil $\mathrm{N}$ store. The weak negative correlation between $\mathrm{NO}_{2}$ concentration and foliar $\delta^{15} \mathrm{~N}$ could indicate increased $\mathrm{N}$ leaching at the high exposure sites (Pardo et al. 2006). However, given the lack of response of the other ecosystem parameters, it is likely that the increased $\mathrm{N}$ content may be caused by direct uptake of $\mathrm{N}$ by the foliage from the atmosphere, particularly as the mean isotopic signature of Pinus banksiana foliage in the region is approximately $-2.8 \%$ which is similar to the isotopic signature of the $\mathrm{NO}_{\mathrm{x}}$ emissions from the oil sands industry (B. Mayers, pers. comm.). 
Regardless of lichen or foliar concentration, according to the theory of Aber et al. (1989) the response we are seeing is indicative of very early stages (Stage 1) of N saturation. Boreal ecosystems are naturally $\mathrm{N}$-limited and many of the species are adapted to the low-nutrient availability through various mycorrhizal associations and efficient internal N-cycling, and any substantial input via deposition has the potential to change these ecosystems (Bobbink et al. 1995; Fenn et al. 2003; Emmett 2007). Moreover, according to Warazoniak et al. (1997) it is these ecosystems, growing on sandy soils with low precipitation during the growing season, that are particularly vulnerable to the adverse impacts caused by industrial air pollution.

\subsection{Critical levels and loads for $N$}

Impacts of $\mathrm{N}$ on natural ecosystems are defined in terms of critical levels and loads. Critical levels or loads are typically defined as the minimum input of one or more pollutants to receptors, such as plants or ecosystems, that causes a "significant harmful effect" (Nilsson \& Grennfelt 1988). In order to establish reliable critical loads for $\mathrm{N}$ it is essential to understand the effects of $\mathrm{N}$ upon these ecosystems. Deposition gradients, according to Pardo et al. (2007), may be substituted as a space-fortime estimate, with potential for providing information about advanced stages of impact caused by increased $\mathrm{N}$ inputs compared with sites receiving lower inputs.

Under the UNECE's Convention on Long-Range Transboundary Air Pollution (CLRTAP), empirically derived ecosystem-specific critical levels and loads for $\mathrm{N}$ have been developed (UNECE 2004). Currently an average annual critical exposure level (air concentration) for $\mathrm{NO}_{2}$ is $30 \mu \mathrm{g} \mathrm{m}^{-3}$. Further, it was recently recommended that the existing annual critical exposure level for $\mathrm{NH}_{3}\left(8 \mu \mathrm{g} \mathrm{m}^{-3}\right)$ be reduced to $1 \mu \mathrm{g} \mathrm{m}^{-3}$ for lichen and bryophytes and $3 \mu \mathrm{g} \mathrm{m}^{-3}$ for higher plants based on evidence from the field (Cape et al. 2009). Three of the study sites $(212,213, \mathrm{H} 4)$ exceed this recommended annual exposure level for lichen and bryophytes for $\mathrm{NH}_{3}$ based on a three year annual average, and a total of six out of the eight study sites $(210,212$, 213, H2, H4, L1) exceed this level based on measured annual averages.

For terrestrial ecosystems, the critical load for $\mathrm{N}$ is set between 10 and $20 \mathrm{~kg} \mathrm{~N}^{-1} \mathrm{y}^{-1}$, based on changes in mineralization, nitrification with potential nitrate leaching, changes in species composition, increased forest susceptibility to pathogens and decreased epiphytic lichens (UNECE 2004, Tab. 5.1). However, a study by Nordin et al. (2005) in northern Sweden found important vegetation changes at $6 \mathrm{~kg} \mathrm{~N} \mathrm{ha}^{-1} \mathrm{y}^{-1}$ and recommended that the critical load be lowered to this level. Accordingly, deposition to all eight study sites would exceed this level under the high deposition estimate. However, given the current uncertainties regarding appropriate dry deposition velocities for the region, and based on literature estimates for similar ecosystems, in addition to recent observations in Canada, there is currently more confidence in the low deposition estimate.

Numerous studies have found that $\mathrm{N}$ critical loads for acidification may be substantially different from $\mathrm{N}$ critical loads for eutrophication effects, and the effects or responses themselves are difficult to classify as one or the other (Bobbink et al. 1992; Emmett 2007). Currently, a branch of Cumulative Environmental Management Association (CEMA) titled the $\mathrm{NO}_{\mathrm{x}}-\mathrm{SO}_{2}$ Management Working Group (NSMWG), which focuses on industry-related emissions as they pertain to acidification and eutrophication, are reviewing management frameworks designed to determine appropriate critical loads for $\mathrm{N}$ within the AOSR region, with jack pine stands having been identified as particularly sensitive.

Although the biogeochemical responses to $\mathrm{N}$ exposure are apparent in this study, the dynamic nature and potentially delayed response of soils and therefore ecosystem $\mathrm{N}$ cycling, suggests species composition may be a more reliable, and possibly more sensitive indicator of negative effects caused by increased $\mathrm{N}$ exposure (Bowman et al. 2006). It is therefore recommended that vegetation changes, such as epiphytic lichen decline and species shifts from nitrophilic to nitrophilous species be explored.

\section{CONCLUSIONS}

The effects of increased $\mathrm{N}$ deposition are complex and the potential for $\mathrm{N}$ saturation and subsequent acidification and eutrophication are issues of concern in the AOSR. The results of this study clearly show that $P$. banksiana plots are responding to increased $\mathrm{N}$ exposure through increased foliar and lichen $\mathrm{N}$ content. While uncertainty remains around $\mathrm{TN}$ deposition, there is the potential that current air concentration and TN deposition may have long-term negative effects according to some of the latest recommended critical levels and loads.

\section{ACKNOWLEDGEMENTS}

Financial support for this study was provided by the Cumulative Environmental Management Association (CEMA) and a Natural Sciences and Engineering Research Council (NSERC) Collaborative Research and Development Grant awarded to SAW and JA. This research was undertaken, in part, thanks to funding from the Canada Research Chairs Program and an NSERC Discovery grant. The authors gratefully acknowledge the Wood Buffalo Environmental Association (WBEA) for providing logistic support and soil, foliage and lichen data, M. Hansen (WBEA) and A. Bytnerowicz (USDA) for providing the passive air concentration data, M. Maloney (Trent University) for his GIS expertise, M. Isaacs (Trent University) for the natural abundance analysis and L. Turchenek (AMEC) and D. Brown (WBEA) for taking the time out of their busy 
schedules to ship soil samples. The authors would also like to acknowledge and the Canadian National Atmospheric Chemistry (NAtChem) database and its contributing agencies/organisations for providing precipitation chemistry data.

\section{REFERENCES}

Aber, J.D., K.J. Nadelhoffer, P. Steudler \& J.M. Melillo. 1989. Nitrogen saturation in northern forest ecosystems: Excess nitrogen from fossil fuel combustion may stress the biosphere. BioScience, 39: 378-386.

Aber, J., W. McDowell, K. Nadelhoffer, A. Magill, G. Berntson, M. Kamakea, S. McNulty, W. Currie, L. Rustad \& I. Fernandez. 1998. Nitrogen saturation in temperate forest ecosystems. BioScience, 48: 921-934.

AMEC Earth \& Environment Limited. 2001. Jack pine acid deposition monitoring network site selection 2000. Prepared for: Wood Buffalo Environmental Association, Fort McMurray: $32 \mathrm{pp}$.

Atari, D.O., I. Luginaah, X. Xu \& K Fung. 2008. Spatial variability of ambient nitrogen dioxide, and sulfur dioxide in Sarnia, "Chemical Valley", Ontario, Canada. J. Toxicol. Environ. Health, 71: 1572-1581.

Berryman, S., L. Geiser \& G. Brenner. 2004. Depositional gradients of atmospheric pollutants in the Athabasca Oil Sands Region, Alberta, Canada: an analysis of lichen tissue and lichen communities. Report to the Terrestrial Environmental Effects Monitoring Committee of the Wood Buffalo Environmental Association: $171 \mathrm{pp}$.

Bobbink, R., D. Boxman, E. Fremstad, G. Heil, A. Houdijk \& J. Roelofs. 1992. Critical loads for nitrogen eutrophication of terrestrial and wetland ecosystems based upon changes in vegetation and fauna. In: P. Grennfelt \& E. Thornelöf (Eds), Critical loads for nitrogen. Nordic Council of Ministers, Copenhagen: $41 \mathrm{pp}$.

Bobbink, R. \& J.G.M. Roelofs. 1995. Nitrogen critical loads for natural and semi-natural ecosystems: the empirical approach. Water Air Soil Pollut., 85: 2413-2418.

Bruteig, I.E. 1992. The epiphytic lichen Hypogymnia physodes as a biomonitor of atmospheric nitrogen and sulphur deposition in Norway. Earth Environ. Sci., 26: 27-47.

Burnett, R.T., S. Cakmak \& J.R. Brook. 1998. The effect of the urban ambient air pollution mix on daily mortality rates in 11 Canadian cities. Can. J. Publ. Health, 89: 152156.

Bytnerowicz, A., W. Fraczek, S. Schilling \& D. Alexander. 2010. Spatial and temporal distribution of ambient nitric acid and ammonia in the Athabasca Oil Sands Region, Alberta. J. Limnol., 69(Suppl. 1): 11-21. DOI: 10.3274/ JL10-69-S1-03.

Bytnerowicz, A., M.J. Sanz, M.J. Arbaugh, P.E. Pagett, D.P. Jones \& A. Davila. 2005. Passive sampler for monitoring ambient nitric acid $\left(\mathrm{HNO}_{3}\right)$ and nitrous acid $\left(\mathrm{HNO}_{2}\right)$ concentrations. Atmos. Environ., 39: 2655-2660.

Callesen, I. \& P. Gundersen. 2003. Nitrogen sinks in boreal ecosystems. Report prepared for Cumulative Environmental Management Association-Wood Buffalo Region: $73 \mathrm{pp}$.

Cape, J.N., L.J. van der Eerden, L.J. Sheppard, I.D. Leith \& M.A. Sutton. 2009. Evidence for changing the critical level for ammonia. Environ. Pollut., 157: 1033-37.

C.E. Jones (\& Associates Ltd). 2007. Terrestrial Environmental Effects Monitoring: Acidification monitoring program, 2004 sampling event report for soil, lichen, understory vegetation and forest health and productivity. Prepared for: Wood Buffalo Environmental Association Terrestrial Environmental Effects Monitoring Committee Fort McMurray, Alberta: 198 pp.
Chapin, F. S., III. 1980. The mineral nutrition of wild plants. Ann. Rev. Ecol. Systematics, 11: 233-260.

Crawley, M.J. 1983. Herbivory: The Dynamics of AnimalPlant Interactions. Blackwell Scientific Publications, Oxford: $437 \mathrm{pp}$.

Dahlman, L. \& J. Persson. 2003. Carbon and nitrogen distribution in the green algae lichens Hypogymnia physodes and Platismata glauca in relation to nutrient supply. Planta, 217: 41-48.

Dise, N. B. \& R.F. Wright. 1995. Nitrogen leaching from European forests in relation to nitrogen deposition. For. Ecol. Manage., 71: 153-171.

Emmett, B.A., O.J. Kjønaas, P. Gundersen, C. Koopmans, A. Tietema \& D. Sleep. 1998. Natural abundance of ${ }^{15} \mathrm{~N}$ in forests across a nitrogen deposition gradient. For. Ecol. Manage., 101: 9-18.

Emmett, B.A. 2007. Nitrogen saturation of terrestrial ecosystems: Some recent findings and their implications for our conceptual framework. Water Air Soil Pollut. Focus, 7: 99-109.

Encke, B.G. 1986. Stickstoff und Waldsterben. Allg. Forstzeitschr, 37: 922-923.

Eno, C.F. 1960. Nitrate production in the field by incubating the soil in polyethylene bags. Soil Sci. Soc. Am. Proc., 24: 277-279.

Environment Canada. 2004. Canadian acid deposition: science assessment. Environment Canada Meteorological Service.

Fenn, M.E., J. S. Baron, E.B. Allen, H.M. Rueth, K.R. Nydick, L. Geiser, W.D. Bowman, J.O. Sickman, T. Meixner, D.W. Johnson \& P. Neitlich. 2003. Ecological effects of nitrogen deposition in the western United States. BioScience, 53: 411-420.

Fenn, M.E., L. Geiser, R. Bachman, T.J. Blubaugh \& A. Bytnerowicz. 2007. Atmospheric deposition inputs and effects on lichen chemistry and indicator species in the Columbia River Gorge, USA. Environ. Pollut.,146: 77-91.

Galloway, J.N. 1998. The global nitrogen cycle: changes and consequences. Environ. Pollut.,102: 15-24.

Gilbert, N.L., M.S. Goldberg, B. Beckerman, J.R. Brook \& M. Jerrett. 2005. Assessing spatial variability of ambient nitrogen dioxide in Montréal, Canada, with land-use regression model. Air Waste Manage. Assoc., 55: 1059-1063.

Golder Associates. 2003. Evaluation of historic and future acid deposition effects on soil in the Athabasca oil sands region. Calgary. Prepared for the Cumulative Environmental Management Association.

Grodzińska-Jurczak, M. \& G. Szarek-Lukaszewska. 1999. Evaluation of $\mathrm{SO}_{2}$ and $\mathrm{NO}_{2}$-related degradation of coniferous forest stands in Poland. Sci. Tot. Environ., 241: 1-15.

Hanson, P.J. \& S.E. Lindberg. 1991. Dry deposition of reactive nitrogen compounds: A review of leaf, canopy and non-foliar measurements. Atmos. Environ., 25: 1615-1634.

Kirby, C., A. Greig \& T. Drye. 1998. Temporal and spatial variations in nitrogen dioxide concentrations across an urban landscape: Cambridge, UK. Environ. Monit. Assess., 52: 65-82.

Kulbin, E. 1990. A survey of element concentrations in the epiphytic lichen Hypogymnia physodes in Finland in 1985-86. In: Kauppi, P., Kenttamies, K. \& P. Anttila (Eds), Acidification in Finland. Springer-Verlag Heidelberg: pp. 421-446.

Lebret, E., D. Briggs, H. van Reeuwijk, P. Fischer, K. Smallbone, H. Harssema, B. Kriz, P. Gorynski \& P. Elliott. 2000. Small area variations in ambient $\mathrm{NO}_{2}$ concentrations in four European areas. Atmos. Environ., 34: 177-185.

Lillyman, C \& K. Buset (Eds). 2008. 2008 Canadian atmospheric assessment of agricultural ammonia. National Agri-Environmental Standards Technical Series. Report No. 4-1: 441 pp. 
Lovett, G.M., K.C. Weathers \& M.A. Arthur. 2000. Nitrogen saturation and retention in forested watershed of the Catskill Mountains, New York. Ecol. Appl., 10: 73-84.

McNulty, S.G., J.D. Aber \& R.D. Boone. 1991. Spatial changes in forest floor and foliar chemistry of spruce-fir forests across New England. Biogeochem., 14: 13-29.

McNulty, S.G, J.D. Aber \& S.D. Newman. 1996. Nitrogen saturation in a high elevation New England spruce-fir stand. For. Ecol. Manage., 84: 109-121.

Munson, A.D. \& V.R. Timmer. 1995. Soil nitrogen dynamics and nutrition of pine following silvicultural treatments in boreal and Great Lakes-St. Lawrence plantations. For. Ecol. Manage., 76: 169-179.

Nadelhoffer, K.J. \& B. Fry. 1994. Nitrogen isotopes in forest ecosystems. In: K. Lajtha \& R.H. Michner (Eds), Stable isotopes in ecology and environmental science. Blackwell Scientific Publishers, Cambridge, UK: 22-44.

Nihlgård, B. 1985. The ammonium hypothesis: An additional explanation to the forest dieback in Europe. Ambio, 14: 2-8.

Nilsson, J. \& P. Grennfelt (Eds). 1988. Critical loads for sulphur and nitrogen. Miljørapport 1988:15, NORD 1998:097, Nordic Council of Ministers, Copenhagen, Denmark: 418 pp.

Nordin, A., J. Strengbom, J. Witzell, T. Näsholm \& L. Ericson. 2005. Nitrogen deposition and the biodiversity of boreal forests: Implications for the nitrogen critical load. Ambio, 34: 20-24.

$\mathrm{NO}_{\mathrm{x}}-\mathrm{SO}_{2}$ Management Working Group. (NSMWG). 2008. Proposed interim nitrogen (Eutrophication) management recommendations and work plan for the Regional Municipality of Wood Buffalo area. Prepared for CEMA: 58 pp.

Pardo, L.H., P.H. Templer, C.L. Goodale, S. Duke, P.M. Groffman, M.B. Adams, P. Boeckx, J. Boggs, J. Campbell, B.Colman, J.Compton, B. Emmett, P. Gundersen, J. Kjønaas, G. Lovett, M. Mack, A. Magill, S. Ollinger, D. Ross, H. Rueth, L. Rustad, P. Schaberg, S. Schiff, P. Schleppi, J. Spoelstra \& W. Wessel. 2006. Regional assessment of N saturation using foliar and root $\delta^{15} \mathrm{~N}$. Biogeochem., 80: 143-171.

Pardo, L.H., S.G. McNulty, J.L. Boggs \& S. Duke. 2007. Regional patterns in foliar $15 \mathrm{~N}$ across a gradient of nitrogen deposition in the northeastern US. Environ. Pollut., 149: 293-302.

Peters, K. \& G. Bruckner-Schatt. 1995. The dry deposition of gaseous and particulate nitrogen compounds to a spruce stand. Water Air Soil Pollut., 85: 2217-2222.

Rihm, B. 1994. Critical loads of acidity for forest soils and alpine lakes. Federal Office of Environment, Forests and Landscape (FOEFL), Berne: $68 \mathrm{pp}$.

Roadman, M.J., J.R. Scudlarka, J.J. Meisinger \& W.J. Ullman. 2003. Validation of Ogawa passive samplers for the de- termination of gaseous ammonia concentrations in agricultural settings. Atmos. Environ., 37: 2317-2325.

Robinson, D. 2001. $\delta^{15} \mathrm{~N}$ as an indicator of the nitrogen cycle. Trends Ecol. Evol., 16:153-162.

Siccama, T.G., M. Bliss \& H.W. Vogelmann. 1982. Decline of red spruce in the green mountains of Vermont. Bull. Torrey Bot. Club, 109: 163-168.

Smith, V.H., G.D. Tilman \& J.C. Nekola. 1999. Eutrophication: impacts of excess nutrient inputs on freshwater, marine, and terrestrial ecosystems. Environ. Pollut., 100:179196.

Sutton, M.S., C.E.R. Pitcairn \& C.P. Whitfield. 2004. Bioindicator and biomonitoring methods for assessing the effects of atmospheric nitrogen on statutory nature conservation sites. Joint Nature Conservation Committee (JNCC) Report No. 356.

Tamm, C.O. 1991. Nitrogen in terrestrial ecosystems. Questions of productivity, vegetational changes, and ecosystem stability. Springer Verlag, Berlin: $115 \mathrm{pp}$

Tjoelker, M.G., P.B. Reich \& J. Oleksyn. 1999. Changes in leaf nitrogen and carbohydrates underlie temperature and $\mathrm{CO}_{2}$ acclimation of dark respiration in five boreal tree species. Plant Cell Environ., 22: 767-778.

UNECE. 2004. LRTAP mapping manual on methodologies and criteria for modelling and mapping critical loads and levels and air pollution effects, risks and trends. Available: [Online] icpmapping.org.

Vet, R. \& M. Shaw. 2006. Wet and dry deposition fields for Alberta 1994-1998. Environment Canada, Toronto, Ontario.

Vitousek, P.M., J.D. Aber, R.W. Howarth, G.E. Likens, P.A. Matson, D.W. Schindler, W.H. Schlesinger \& D.G. Tilman. 1997. Human alteration of the global nitrogen cycle: Sources and consequences. Ecol. Appl., 7: 737-750.

Watmough, S.A., J. Aherne, C. Alewell, P. Arp, S. Bailey, T. Clair, P. Dillon, L. Duschesne, C. Eimers, I. Fernandez, N. Foster, T. Larssen, E. Miller, M. Mitchell \& S. Page. 2005. Sulphate, nitrogen and base cation budgets at 21 forested catchments in Canada, the United States and Europe. Environ. Monit. Assess., 109: 1-36.

Wawrzoniak, J., J. Malachowska \&J. Wójcik. 1997. Stan uszkodeznia lasów w Polsce w 1996 r na podstawie badań monitoringowych. Warszawa: PIOŚ, Biblioteka Monitoring Środowiska, 1996:1997.

Zhang, L., J.R. Brook \& R. Vet. 2003. A revised parameterization for gaseous dry deposition in air-quality models. Atmos. Chem. Phys., 3: 2067-2082.

Zhang, L., R. Vet, J.M O'Brien, C. Mihele, Z. Liang \& A.Wiebe. 2009. Dry deposition of individual nitrogen species at eight Canadian rural sites. J. Geophys. Res., 114: D02301. 